\title{
The Scientific and Life Path of Academician O.M. Belotserkovsky
}

\section{I.B. Petrov}

Moscow Institute of Physics and Technology, Dolgoprudny, Russian Federation

$$
\square \text { petrov@mipt.ru }
$$

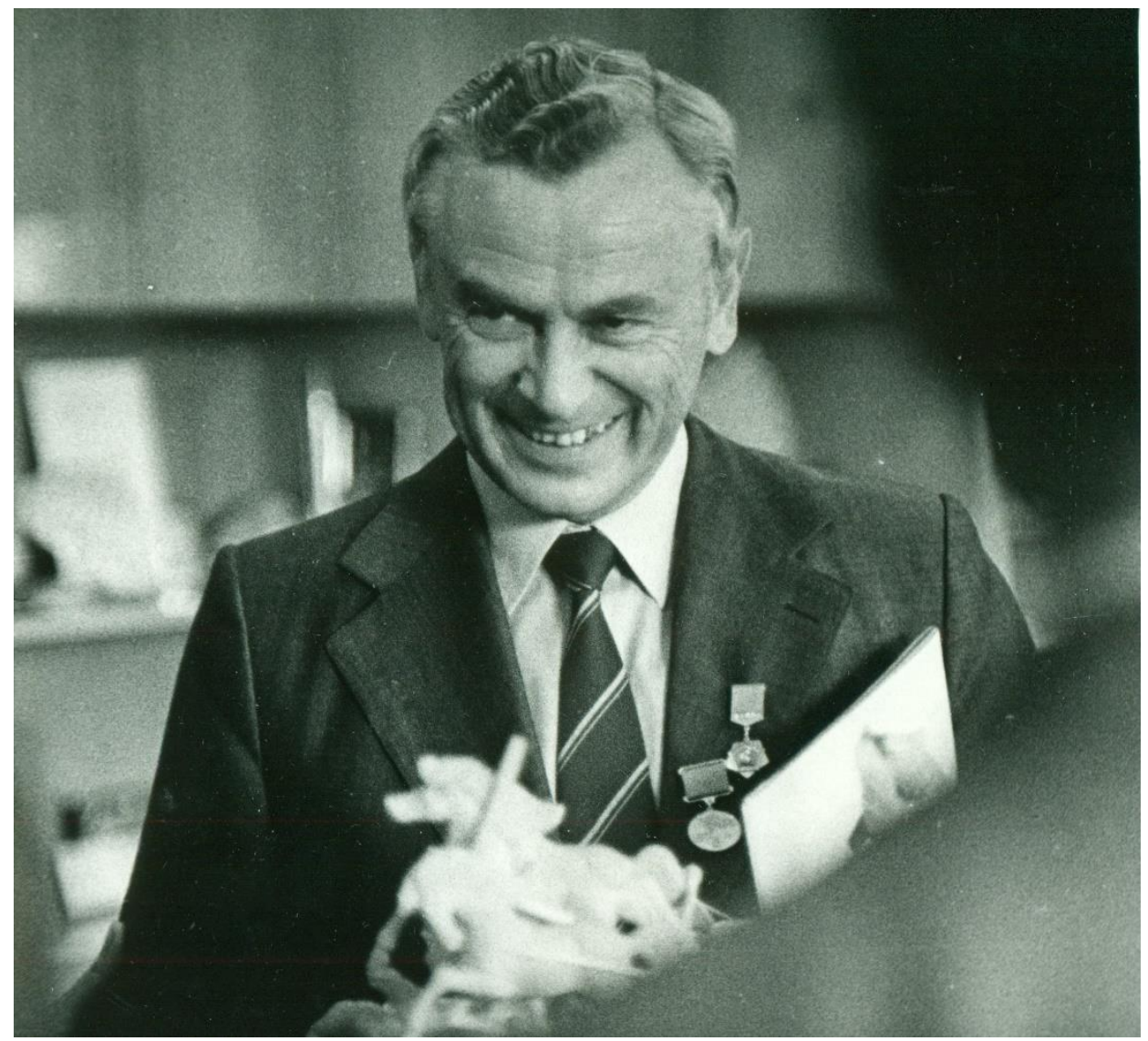

29.08.1925-14.07.2015

Oleg Mikhailovich Belotserkovsky

Oleg Mikhailovich Belotserkovsky is an outstanding scientist and teacher, a full member of the world-famous Russian Academy of Sciences, a mathematician and mechanic, the founder of a number of scientific areas in numerical methods for solving problems of continuum mechanics, mathematical modeling of physical processes, rector of the Moscow Institute of Physics and Technology, director of the Institute of Automation Design of the Russian Academy of Sciences Oleg Mikhailovich Belotserkovsky.

Oleg Mikhailovich was born in the city of Livny, Oryol region in a family of teachers. After graduating from high school, he entered MVTU im. Bauman, then continued his studies at the Faculty of Physics and Technology of Moscow State University, and in 1952 he graduated from the Moscow Physics and Technology Institute. After graduating from MIPT, Oleg Mikhailovich was assigned to 
the V.A. Steklov, USSR Academy of Sciences, in 1955 moved to the Computing Center of the USSR Academy of Sciences, where he continued his research work with the full member of the USSR Academy of Sciences Anatoly Alekseevich Dorodnitsyn, an outstanding scientist, mathematician and mechanic who owns well-known works in the field of viscous fluid mechanics. The joint work of these two great scientists continued until 1994, when Anatoly Alekseevich passed away. Oleg Mikhailovich not only continued the work of Academician A.A. Dorodnitsyna, but also created his own unique world-class scientific school.

In 1972, O.M. Belotserkovsky was elected a corresponding member of the USSR Academy of Sciences, in 1979 - a full member of the USSR Academy of Sciences. In addition, he was an academician of the International Astronomical Federation, was the first deputy academician secretary of the Department of Informatics, Computer Engineering and Automation of the USSR Academy of Sciences. He was awarded a prize to them. NOT. Zhukovsky first degree and the gold medal «For the best work on the theory of aviation», was awarded high government awards.

Scientific interests of academician O.M. Belotserkovsky is associated with the development of numerical methods and problem solving, aerodynamics of spacecraft, hydrophysics, plasma physics, mechanics of a deformable solid, and a number of other issues of mathematical modeling. O.M. Belotserkovsky created a well-known scientific school in the field of computational mechanics in the world scientific community.

For the first time he was able to solve one of the most important problems of aerodynamics the supersonic flow around a blunt body with a departing shock wave. These works have a global priority and are an outstanding contribution to the theory and practice of space research. The method he proposed is the basic one in aerodynamic calculations of hypersonic aircraft.

Developed with the active participation of Oleg Mikhailovich, new computational methods «large particles», «conservative flow method», «splitting method», «grid-characteristic method», «statistical particle method»- have found wide application in the work of various research institutes and design bureaus of our country and have received great recognition in the scientific world.

O.M. Belotserkovsky and his students obtained fundamental theoretical results in such relevant areas of computational mechanics and physics as transonic aerodynamics, spatially unsteady flow around bodies of complex shape, dynamics of a viscous heat-conducting gas, modeling of statistical processes based on Boltzmann equations, etc. In the framework of a computational experiment, he together with students also boldly took up the simulation of magnetohydrodynamic instability in thermonuclear reactors.

Oleg Mikhailovich's scientific interests included the numerical solution of problems of plasma physics, thermonuclear fusion, turbulence, problems of mechanics of a deformable solid, computational medicine and biology, the development of approaches to solving the problem of mapping numerical methods to the architecture of multiprocessor high-performance computers. Of particular interest are developments devoted to the direct numerical study of the complex phenomena of turbulence and hydrodynamic instability.

Numerical modeling of separated flows, ordered structures in turbulent flows, and hydrodynamic instabilities allowed OM Belotserkovsky put forward a number of fundamental principles that laid the foundation for a new constructive approach to numerical modeling of urgent and complex problems of nonlinear mechanics of continuous media. These works were highly 
appreciated by a group of scientists from the Los Alamos Laboratory in the United States under the leadership of Harlow, where academician Belotserkovsky in 1994-1995. read a series of lectures and held a number of seminars.

In the following years, he dealt with the same problems, creating the Center for Computer Modeling on the basis of the Central Aerohydrodynamic Institute (Zhukovsky, Moscow Region). Under his leadership, numerical methods were also developed to solve the urgent problems of the dynamic strength of composite aircraft structures. At the same time, Oleg Mikhailovich and his students began work on the numerical solution of the problems of seismic stability of nuclear facilities and aerodynamics facilities of the nuclear industry and aerodynamics together with the Russian Federal Nuclear Center in Sarov.

Oleg Mikhailovich conducted a great organizational and pedagogical work. For a quarter century, O.M. Belotserkovsky was the rector of the Moscow Institute of Physics and Technology. Here is the opinion of his successor as rector of the Moscow Institute of Physics and Technology, corresponding member of the RAS N.V. Karlova: «... it was Oleg Mikhailovich who brilliantly used the organic PhysTech mobility, the ability to quickly and efficiently respond to the needs of the day. In the period from 1964 to 1987, he created about 70 new graduating (basic) departments, training physical and mathematical engineers in a wide range of specialties in fundamental and applied science - from elementary particle physics to space research, from global ocean monitoring to microbiology, from mathematical control problems to the dynamics of large systems. Moreover, in the same period, the Far Eastern, Ural and Kiev branches of the Moscow Institute of Physics and Technology were created, students, teachers and basic departments were completely incorporated into the system of Physics and Technology. In a word, Academician Belotserkovsky created the mighty and kind of great empire of Fiztekh».

At the Institute for Design Automation, Oleg Mikhailovich launched a wide range of activities in the development of software and high-performance super-computers with parallel architecture in various scientific fields. In addition, the complex application of expert systems and mathematical modeling was studied for solving special-purpose problems; Research is being carried out in the fields of fundamental and applied CAD applications for various areas of the national economy.

For ten years, at the initiative of Oleg Mikhailovich, IAP RAS actively collaborated with scientific centers of India. The Izvestia newspaper on December 16, 1999 wrote: «Russia and India have agreed to jointly organize a Center for Advanced Computer Research ... The project will be supported by the Institute for Design Automation of the Russian Academy of Sciences and the Center for High Performance Computing of the Indian Electronics Department. The Russian-Indian center will be located in Moscow ... According to the director of IAP RAS Oleg Belotserkovsky, the center will operate on the basis of the Indian supercomputer «PARAM-10000», capable of performing 70100 billion operations per second. According to Belotserkovsky, this is the first computer of such power in Russia».

Academician O.M. Belotserkovsky prepared about forty doctors of science and dozens of candidates of science. For success in the scientific, pedagogical and organizational activities of OM Belotserkovsky was awarded the Orders of Lenin, the October Revolution, three orders of the Red Banner of Labor, the Order of Merit for the Fatherland, III degree and medals. 


\section{LIST OF BASIC SCIENTIFIC WORKS O.M. BELOTSERKOVSKY Monographs}

1. The flow around blunt bodies with a supersonic gas stream. Theoretical and experimental studies. M.: VTs AN SSSR, 1967.400 p.

2. Numerical methods for solving problems of mechanics of continuous media. NASA TTF667, Washington, $1972.221 \mathrm{p}$.

3. Numerical study of modern problems of gas dynamics. M.: Nauka, 1974.398 s. (Together with Yu.P. Golovachev, V.G. Grudnitsky, Yu.M. Davydov, V.K. Dushin, Yu.P. Munkin, KM Magomedov, V.K. Molodtsov, F.D. Popov, A.I. Tolstoy, V.N. Fomin, AC Kholodov.)

4. The method of large particles. Computational experiment. M.: Nauka, 1982.258 p. (Coll. With Yu.M. Davydov.)

5. Numerical modeling in the mechanics of continuous media. (Ed. 2nd, rev. And add.) M.: Nauka, 1994.442p.

6. Computer science and medicine / Ed. O.M. Belotserkovsky and A.B. Vinogradov. Ser. «Cybernetics:unlimited possibilities and possible limitations» M.: Nauka, 1997. 206 p.

7. Dynamics of spatial vortex flows in an inhomogeneous atmosphere. Computational experiment. M.: Janus-K, 2000.456 s. (Together with V.A. Andryushchenko, Yu.D. Shevelev.)

8. Modern solution method for nonlinear multidimensional problems. Mathematics, mechanics, turbulence. Edwin Mellen Press, 2000.411 p.

9. A numerical experiment in turbulence: from order to chaos. M.: Nauka, 2000.224 s. (With A.M. Oparin.)

10. Turbulence and instabilities. Edwin Mellen Press, 2000.345 p. (Rev. and Extended edition, Moscow: press, 2003.450 p.)

11. Computer models and medical progress / Ed. O.M. Belotserkovsky, A.C. Kholodova. M.: Nauka, 2001.302 p.

12. Turbulence: new approaches. M.: Nauka, 2002.286 p. (Together with A.M. Oparin and V.M. Chechetkin.)

13. Computer and the brain / Ed. O.M. Belotserkovsky. M.: Nauka, 2005.332 p.

14. Turbulence: New approaches. Rev. and Extended ed. Cambridge Internat. Sei. Pubis. Ltd, 2005.288 p. (With A.M. Oparin and V.M. Chechetkin.)

\section{Science articles}

1. Flow around a circular cylinder with a deflected shock wave // Dokl. USSR Academy of Sciences. 1957. V. 113. № 3. P. 509-512.

2. Flow around an arbitrary symmetric profile with a departing shock wave: Abstract. dis. ...Cand. Phys.-Math. sciences. M.: Mat. Institute of Academy of Sciences of the USSR, 1957.

3. Flow around a symmetric profile with a deflected shock wave // Prikl. mate. and mehan. 1958. V. 22. № 2. P. 206-219.

4. Algorithms for numerical schemes of the method of integral relations for calculating mixed gas flows // Zh. Vychisl. mate. and mate. physical 1966. V.6. № 6. P. 1064-1081. (Together with A. Bulekbaev and V.G. Grudnitsky.)

5. Transonic flows behind a departing shock wave // Zh. Vychisl. mate. and mate. physical 1969.V. 9. № 4. P. 908-931. (Together with E.G. Shifrin.) 
6. The non-stationary method of «large particles» for gas-dynamic calculations // Zh. Vychisl. mate. and mate. physical 1971. V. 11. № 1. P. 182-207. (Coll. With Yu.M. Davydov.)

7. Conservative method of «flows» and calculation of viscous heat-conducting gas flow past a finite-size body II Zh. Vychisl. mate. and mate. physical 1973. Vol. 13. № 2. P. 385-397. (Together with L.I. Severinov.)

8. Hypersonic flow around blunt bodies with a stream of emitting gas // Zh. Vychisl. mate. and mate. physical 1974.V. 14. № 4. P. 992-1003. (Together with S.D. Osetrova, V.N. Fomin, A.C. Kholodov.)

9. The splitting method as applied to solving problems of the dynamics of a viscous incompressible fluid // J. Comput. mate. and mate. physical 1975.Vol. 15. № 1. P. 197-207. (Together with V.A. Gushchin and V.V. Shchennikov.)

11. The statistical method of particles in cells for solving problems of the dynamics of a rarefied gas. P. Computational aspects of a method // J. Comput. mate. and mate. physical 1975.Vol. 15. № 6. P. 1553-1567. (Coll. With V.E. Yanitsky.)

12. Numerical modeling of some problems of laser compression of shells // J. Comput. mate. and mate. physical 1978. V. 18. № 2. P. 420-444. (Together with V.V. Demchenko, V.I. Kosarev, A.C. Kholodov.)

13. Direct numerical simulation of complex flows of gas dynamics based on the Euler, NavierStokes and Boltzmann equations // Direct numerical. gas flow modeling. Number experiments in gas dynamics. (Karmanovskaya lecture.) M., 1978.P. 6-64.

14. Numerical study of some problems of gas dynamics by grid-characteristic methods // VI Intern. conf. by number methods in hydrodynamics. Tbilisi, 1978; T.P.M., 1978.P. 37-47. (With A.C. Kholodov.)

15. On the numerical solution of problems for multidimensional equations of hyperbolic type // Gas and wave dynamics. M., 1978. № 3. P. 6-17. (With A.C. Kholodov.)

16. New numerical models in continuum mechanics and plasma physics: Rept. Akad. Wiss. DDR Zentralinst. Math, und Mech. 1980. № 5.792 p.

17. The study of unsteady gas flows with a complex internal structure by methods of integral relations // Zh. Vychisl. mate. and mate. physical 1980. V. 20. № 6. P. 1400-1415. (Together with V.G. Grudnitsky.)

18. The use of mathematical methods and computer technology in cardiology and surgery / Ed. O.M. Belotserkovsky // Vopr. cybernetics. M., 1983. № 85. P. 3-17.

19. Numerical simulation of non-stationary periodic flow of a viscous fluid in the wake of a cylinder // J. Comput. mate. and mate. physical 1984. V 24. P. 8. № 1204-1216. (Together with S.O. Belotserkovsky, V.A. Gushchin.)

20. Direct numerical simulation of free developed turbulence // Zh. Vychisl. mate. and mate. physical 1985. V 25. № 12. pp 1856-1882.

21. Pipelining algorithms for solving mathematical physics problems on the basis of parametric correction difference schemes // Problems. cybernetics. M., 1986. № 99. P. 10-35. (Together with A.I. Panarin, V.V. Shchennikov.) 
22. Grid-characteristics methods in multidimensional problems of gas dynamics / Ed. by O.M. Belotserkovskii and V.P. Shidlovsky // Current Problems in Comput. Fluid Dynamics. M.: Mir, 1986. P. 125-189. (With A.S. Kholodov and L.I. Turchak.)

24. Method for investigating cleavage of stratified fluid with a free surface // Zh. mate. and mate. physical 1987.V. 27. № 4. P. 594-609. (Akad. Gushchin with VA, VN Koninshinym).

25. Consecutive transition to turbulence in Richtmyer-Meshkov // Dokl. RAS. 1994.V. 334. № 5. P. 581-583. (Coll. With V.V. Demchenko, A.M. Oparin.)

26. Non-stationary three-dimensional numerical modeling of Richtmeier-Meshkov instability // Dokl. RAS. 1997.V. 354. № 2. P. 190-193. (Akad. With VV Demchenko, A.M. Oparin).

27. 2D and 3D comparative study of the Richtmyer-Meshkov instability development // Proc. 6th Int. Workshop Phys. Compressible Turbulent Mixing. Marseille, 1997. P. 86-89 (With V.V. Demchenko, A.M. Oparin.)

28. On majorant schemes on unstructured (chaotic) grids in the space of indefinite coefficients // Zh. Vychisl. mate. and mate. physical 1999.Vol. 39. № 11. P. 1802-1820. (With A.C. Kholodov.)

29. Numerical study of the spatial development of Rayleigh-Taylor instability // Zh. Vychisl. mate. and mate. physical 2000.V. 40. № 7. P. 1098-1103. (Akad. Oparin with A.M.).

30. Direct numerical modeling of turbulence: Coherent structures, laminar-turbulent transition, chaos // Comput. Fluid Dynamics J., Japan Soc. CFD. 2001. V. 10. № 3. P. 280-285. (With E.R. Pavlyukova.)

31. The formation of large-scale structures in the gap between rotating cylinders (RayleighZeldovich problem) // Zh. Vychisl. mate. and mate. physical 2002.V. 42. № 11. P. 1727-1737. (Akad. Oparin with A.M., Chechotkinym VM).

32. On the replacement of grid functions of dependent variables in finite difference equations // Zh. Vychisl. mate. and mate. physical 2002. V. 42. № 2. P. 235-248. (Together with A.B. Konyukhov.)

33. Implementation of universal parallel computations technology to spatial problems described by hyperbolic set of equations // Abstracts of V Internat. Congress on Math. Modeling. Vol. I. Dubna. 2002. 60 p. (With M.N. Antonenko, A.V. Konyukhov, L.M. Kraginskii, S.V. Fortova, A.M. Oparin.)

34. Universal technology of parallel computations for the problems described by systems of the equations of hyperbolic type // A step to super solver Comput. Fluid Dynamics J. 2003. V. 2. № 4. P. 456-466. (With M.N. Antonenko, A.V. Konyukho., L.M. Kraginskii, S.V. Fortova, A.M. Oparin.)

35. Modeling of large-scale atmospheric flow with the help of parallel framework for hyperbolic equations: Abstracts of 8th Japan-Russia Joint Symp. Comput. Fluid Dynamics. Sendai, Japan, 2003. P. 106-110. (With L.M. Kraginskii, A.M. Oparin.)

36. Monte Carlo Methods in Applied Mathematics and Computing aerodynamics // Zh. mate. and mate. physical 2006.V. 46. № 8. P. 1494-1518 (in common with Yu.I. Khlopkov.)

37. Numerical modeling of the effects of mechanical effects on the human brain during traumatic brain injury // Journal of Computational Mathematics and Mathematical Physics. T. 46. № 46. Pp 1171-1720. (Akad. I.B. with Petrov, P.I. Agapov) 


\section{Author:}

Petrov Igor Borisovich, Corresponding Member of the Russian Academy of Sciences, Professor, Doctor of Science in Physics and Maths, Scientific Director of the Department of Computational Physics, Moscow Institute of Physics and Technology (State University), (9 Institutsky per., Dolgoprudny Moscow Region, Russian Federation)

Petrov I.B. - specialist in the field of informatics, applied mathematics, computer modeling, author of 411 scientific (199 in Wos, Scopus, 26 in Q1, Q2) and 24 educational and methodological works, co-author of 6 monographs and 4 ex textbooks; has 3 patents, 3 copyright certificates of state registration of computer programs, is an honorary worker of science and technology of Moscow, an honored professor of MIPT, an honorary professor of Innopolis University and Xi'an University (China), a member of the National Council for Industrial and Applied Mathematics, is a member of section of Mathematical Sciences of the Coordinating Council of the Program of Fundamental Scientific Research in the Russian Federation (2021-2030); for scientific work he was awarded the medal of the Order of Merit to the Fatherland, 2nd degree. Under his leadership, 25 candidate and 3 doctoral dissertations were defended, 1 doctoral dissertation was submitted for defense, it is planned to be presented in 2021. 1 doctoral and 1 candidate dissertation. Petrov I.B. conducts a great deal of teaching work at the departments of informatics and computational mathematics, computational physics of the Moscow Institute of Physics and Technology (45 years of experience), is the head of graduate students and students, the chairman of the SJSC of two universities. Petrov I.B. is a member of the editorial boards of 9 scientific journals, the Academic Council of the MIPT, two Councils of the Russian Academy of Sciences (the Council for Mechanical Engineering, the Council for awarding medals and prizes for young scientists and students), dissertation Councils, is the head of grants of the RFBR, RNF, a member of the RFBR expert council, expert of the Russian Science Foundation, RAS. Three of his students were awarded medals of the Russian Academy of Sciences, one received a high international award for high citation «Research Excelence Award Russia», one is the rector of the University «Innopolis». Petrov I.B. nominated as a candidate for academicians of the Russian Academy of Sciences in the Department of Mathematical Sciences of the Russian Academy of Sciences in the specialty «Applied Mathematics and Informatics» by the Academic Council of MIPT (2019). solutions of spatial dynamic problems in the mechanics of deformable solids on regular and irregular computational grids, the joint method of smooth particles and the grid-characteristic method; numerical solutions of problems of medicine, high-speed interaction of deformable bodies, asteroid hazard, the effect of laser radiation and beams of charged particles on the shells of apparatus are obtained, propagation of elastic and elastoplastic waves, global seismics, seismic exploration, seismic resistance of structures, development of the Arctic shelf of the Russian Federation, strength of composite aviation and space structures. 


\section{Научный и жизненный путь академика О.М. Белоцерковского}

\section{И.Б. Петров}

МГУ им. М.В. Ломоносова факультет Вычислительной математики и кибернетики, Москва, Российская Федерация

$$
\square \text { mamosp@mail.ru }
$$

Олег Михайлович Белоцерковский - выдающийся ученый и преподаватель, действительный член Российской Академии Наук с мировым именем, математик и механик, основоположник ряда научных направлений в численных методах решения задач механики сплошных сред, математическом моделировании физических процессов, ректора Московского физико-технического института, директор Института автоматизации проектирования Российской Академии Наук Олега Михайловича Белоцерковского.

Олег Михайлович родился в г. Ливны Орловской области в семье учителей. После окончания средней школы, он поступил в МВТУ им. Баумана, затем продолжил обучение на физико-техническом факультете Московского государственного университета, а в 1952 году закончил Московский физикотехнический институт. После окончания МФТИ Олег Михайлович был распределен в Математический институт имени В.А. Стеклова АН СССР, в 1955 году перешел в Вычислительный центр АН СССР, где продолжил научно-исследовательскую работу с действительным членом АН СССР Анатолием Алексеевичем Дородницыным, выдающимся ученым, математиком и механиком, которому принадлежат известные работы в области механики вязкой жидкости. Совместная работа этих двух великих ученых продолжалась до 1994-го года, когда ушел из жизни Анатолий Алексеевич. Олег Михайлович не только продолжил работы академика А.А. Дородницына, но и создал свою уникальную научную школу мирового уровня.

В 1972 году О.М. Белоцерковский был избран членом-корреспондентом АН СССР, в 1979 году - действительным членом АН СССР. Кроме того, но являлся академиком международной астрономической федерации, был первым заместителем академика - секретаря Отделения информатики, вычислительной техники и автоматизации АН СССР. Ему присуждена премия им. Н.Е. Жуковского первой степени и золотая медаль «За лучшую работу по теории авиации», награжден высокими правительственными наградами.

Научные интересы академика О.М. Белоцерковского связаны с разработкой численных методов и решением задач, аэродинамики спускаемых космических аппаратов, гидрофизики, физики плазмы, механики деформируемого твердого тела и ряда других вопросов математического моделирования. О.М. Белоцерковским создана хорошо известная в мировом научном сообществе научная школа в области вычислительной механики.

Ему впервые удалось решить одну из важнейших проблем аэродинамики - о сверхзвуковом обтекании затупленного тела с отошедшей ударной волной. Эти работы имеют мировой приоритет и являются выдающимся вкладом в теорию и практику космических исследований. Предложенный им метод, является базовым в аэродинамических расчетах сверхгиперзвуковых летательных аппаратов.

Разработанные при активном участии Олега Михайловича новые вычислительные методы «крупных частиц», «консервативный метод потоков», «метод расщепления», «сеточнохарактеристический метод», «статистический метод частиц»- нашли широкое применение в работе различных НИИ и КБ нашей страны и получили большое признание в научном мире.

О.М. Белоцерковским и его учениками получены фундаментальные теоретические результаты в таких актуальных областях вычислительной механики и физики, как трансзвуковая аэродинамика, пространственно-нестационарное обтекание тел сложной формы, динамика вязкого теплопроводного 
газа, моделирование статистических процессов на базе уравнений Больцмана и др. В рамках вычислительного эксперимента он вместе с учениками также смело взялся за моделирование магнитогидродинамической неустойчивости в термоядерных реакторах.

Область научных интересов Олега Михайловича включала в себя численное решение задач физики плазмы, термоядерного синтеза, турбулентности, задач механики деформируемого твердого тела, вычислительной медицины и биологии, разработку подходов к решению проблемы отображения численных методов на архитектуру многопроцессорных высокопроизводительных ЭВМ. Особый интерес представляют разработки, посвященные прямому численному исследованию сложных явлений турбулентности и гидродинамической неустойчивости.

Численное моделирование отрывных течений, упорядоченных структур в турбулентных течениях и гидродинамических неустойчивостей позволили О.М. Белоцерковскому выдвинуть ряд основополагающих принципов, положивших начало новому конструктивному подходу к численному моделированию актуальных и сложных проблем нелинейной механики сплошных сред. Эти работы получили высокую оценку группы ученых из Лос-Аламосской лаборатории в США под руководством Харлоу, где академик Белоцерковский в 1994 - 1995гг. прочел цикл лекций и провел ряд семинаров.

Над этими же проблемами он занимался и в дальнейшие годы, создав Центр компьютерного моделирования на базе Центрального аэрогидродинамического института (г. Жуковский Московской области). Под его руководством, также разрабатывались численные методы для решения актуальных задач динамической прочности композитных авиационных конструкций. В это же время Олег Михайлович с учениками начали работы по численному решению задач сейсмостойкости сооружений атомной промышленности и аэрогазодинамики совместно с Российским федеральным ядерным центром в г. Сарове.

Олег Михайлович проводил большую организационную и педагогическую работу. В течение четверти века О.М. Белоцерковский был ректором Московского физико-технического института. Приведем мнение его преемника на посту ректора МФТИ, члена-корреспондента РАН Н.В. Карлова: «...именно Олег Михайлович блестяще использовал органичную Физтеху мобильность, способность оперативно и действенно откликаться на потребности дня. В период с 1964 по 1987 годы им было создано около 70 новых выпускающих (базовых) кафедр, готовящих инженеров-физиков и инженеровматематиков в широком диапазоне специальностей фундаментальной и прикладной науке - от физики элементарных частиц до космических исследований, от мониторинга мирового океана до микробиологии, от математических проблем управления до динамики больших систем. Более того, в этот же период были созданы Дальневосточное, Уральское и Киевское отделения МФТИ, студенты, преподаватели и базовые кафедры были полностью инкорпорированы в систему Физтезха. Одним словом - академик Белоцерковский создал могучую и в своем роде великую империю Физтеха.»

В Институте автоматизации проектирования Олег Михайлович развернул широкую деятельность по разработке математического обеспечения и высокопроизводительных супер-ЭВМ с параллельной архитектурой в различных научных областях. Кроме того, изучалось комплексное применение экспертных систем и математического моделирования для решения задач специального назначения; проводятся исследования в областях фундаментальных и прикладных приложений САПР для различных направлений народного хозяйства.

В течение десяти лет по инициативе Олега Михайловича ИАП РАН активно сотрудничал с научными центрами Индии. Газета «Известия» от 16 декабря 1999 года писала: «Россия и Индия пришли к соглашению о совместной организации Центра перспективных компьютерных исследований... Проект будет осуществляться при поддержке Института автоматизации проектирования РАН и Центра высокопроизводительных вычислений Департамента электроники Индии. Российско-индийский центр будет размещен в Москве... Как сообщил директор ИАП РАН Олег Белоцерковский, центр будет функционировать на базе индийского суперкомпьютера «ПАРАМ10000», способного выполнять 70- 100 миллиардов операций в секунду. По словам Белоцерковского, это первый компьютер подобной мощности в России.»

Академик O.M. Белоцерковский подготовил около сорока докторов наук и десятки кандидатов наук. За успехи в научной, педагогической и организационной деятельности О.М. Белоцерковский награжден орденами Ленина, Октябрьской революции, тремя орденами Трудового Красного Знамени, орденом «За заслуги перед отечество» III степени и медалями. 
Автор:

Петров Игорь Борисович, член-корреспондент РАН, профессор, доктор физикоматематических наук, научный руководитель кафедры вычислительной физики, Московский физико-технический институт (государственный университет), г. Долгопрудный Московской обл. (Россия, 141700, г. Долгопрудный Московской обл., Институтский пер., 9)

Петров И.Б. - специалист в области информатики, прикладной математики, компьютерного моделирования, автор 411-и научных (199-в Wos, Scopus, 26-в Q1, Q2 ) и 24-х учебно-методических работ, соавтор 6-и монографий и 4-ех учебников; имеет 3 патента, 3 авторских свидетельства о государственной регистрации программ ЭВМ, является почетным деятелем науки и техники г.Москвы, заслуженным профессором МФТИ, почетным профессором университета Иннополис и Сианьского университета (Китай), членом национального совета по индустриальной и прикладной математике, входит в состав секции Математических наук Координационного Совета Программы фундаментальных научных исследований в РФ ( 2021-2030 г.г.); за научную работу награжден медалью ордена «За заслуги перед Отечеством» 2-ой степени. Под его руководством защищены 25 кандидатских и 3 докторские диссертации, 1 докторская представлена к защите, планируются к представлению в 2021г. 1 докторская и 1 кандидатская диссертации. Петров И.Б. ведет большую преподавательскую работу на кафедрах информатики и вычислительной математики, вычислительной физики МФТИ (стаж-45 лет), является руководителем аспирантов и студентов, председателем ГАК 2-ух университетов. Петров И.Б. входит в состав редколлегий 9-и научных журналов, Ученого Совета МФТИ, двух Советов РАН (Совет по машиностроению, Совет по присуждению медалей и премий для молодых ученых и студентов), диссертационных Советов, является руководителем грантов РФФИ, РНФ, членом экспертного совета РФФИ, экспертом РНФ,„РАН. Три его ученика награждены медалями РАН, один получил высокую международную награду за высокую цитируемость «Research Excelence Award Russia», один является ректором университета «Иннополис». Петров И.Б. выдвинут кандидатом в академики РАН по Отделению математических наук РАН по специальности «Прикладная математика и информатика» Ученым советом МФТИ (2019г.). Основные научные результаты Петрова И.Б.: разработаны и реализованы сеточнохарактеристический метод и гибридные сеточно-характеристические схемы для численного решения пространственных динамических задач механики деформируемых твердых тел на регулярных и нерегулярных расчетных сетках, совместный метод гладких частиц и сеточнохарактеристический метод; получены численные решения задач медицины, высокоскоростного взаимодействии деформируемых тел, астероидной опасности, воздействия лазерного излучения и пучков заряженных частиц на оболочки аппаратов, распространения упругих и упругопластических волн, глобальной сейсмики, сейсморазведки, сейсмостойкости сооружений, освоения Арктического шельфа РФ, прочности композитных авиационных и космических конструкций. 